\title{
Longitudinal Analysis of Stuttering Like Disfluencies as a Treatment Outcome in Early Childhood Stuttering
}

\author{
Soo-Bok Lee ${ }^{a}$, Hyun Sub Sim ${ }^{\mathrm{b}}$ \\ ${ }^{a}$ Department of Speech-Language Therapy $\mathcal{E}$ Aural Rehabilitation, Woosong University, Daejeon, Korea \\ ${ }^{b}$ Department of Communication Disorders, Ewha Womans University, Seoul, Korea
}

Correspondence: Hyun Sub Sim, PhD Department of Communication Disorders, Ewha Womans University, 52 Ewhayeodae-gil, Seodamun-gu, Seoul 03760, Korea

Tel: $+82-2-3277-3538$

Fax: +82-2-3277-2122

E-mail: simhs@ewha.ac.kr

Received: April 10, 2017

Revised: June 5, 2017

Accepted: July 17, 2017

This article is based on a part of the first author's doctoral dissertation from Ewha Womans University (2014).
Objectives: This study longitudinally investigated the treatment outcome of children (age 2 to 5) who stutter (CWS) within 1 year of the onset of stuttering in order to examine whether frequency and types of stuttering like disfluencies (SLD) play a role as a predictor of treatment outcome. Methods: Direct therapy was given to 18 CWS for 18 months and indirect therapy for their parents to change parents' attitudes. Speech samples were collected five times (initial visit and four times every 3 months for 18 months) in order to identify changes in SLD frequency over treatment. Results: The results of the study are summarized as follows. First, the total frequency of SLD was significantly different between the recovered group and the persistence group. That is, SLD decreased in the recovered group while increasing in the persistence group. At 12 and 18 months after treatment, the difference between the two groups was greater than at the other assessment sessions. Second, significant interactions between the group and time of therapy were found in the disrhythmic phonation type. Third, the ratio of SLD in disrhythmic phonation type decreased in the recovery group after 6 months. Conclusion: The results suggest that SLD frequency and disrhythmic phonation type are predictive factors for discriminating between recovered and persistence groups in the treatment for young children who stutter. We also suggest that speech-language pathologists be aware of SLD frequency and disrhythmic phonation's changes at 12 and 18 months after treatment to predict treatment effects in early childhood stuttering.

Keywords: Early childhood stuttering, Stuttering like disfluencies type, Longitudinal study, Recovery group, Persistent group
초기 말더듬아동의 평가에 관련된 중요한 이슈는 말더듬지 않는 아동과 말더듬는 아동을 변별해 줄 수 있는 독특한 비유창성 특성 을 파악하는 것이다(Lee \& Sim, 2015). 왜냐하면 이러한 변별적 비 유창성 특성은 언어치료사가 초기 말더듬아동과 정상적 비유창성 을 보이는 일반아동을 구분하는 데 도움을 주기 때문이다. 하지만 아직 정상적 비유창성과 비정상적 비유창성을 분류하는 절대적인 기준이 없는 실정이다. 초기 말더듬을 보이는 취학 전 아동은 아직 신경학적, 생리학적, 정서적 그리고 언어학적으로 발달과정에 있고, 말과 언어를 포함한 모든 행동의 수행능력이 가변적인 경향이 있기
때문에 변별적인 비유창성 특성을 파악하는 데 더 어려움이 따른 다(Manning, 2010).

말더듬는 사람들이 주로 보이는 비유창성과 일반인들에게도 나 타나는 비유창성을 구분하기 위한 다양한 용어들이 많은 연구들 에서(Campbell \& Hill, 1987; Yairi \& Ambrose, 1992; Yaruss, 1999; Van Riper, 1982; Zebrowski, 2002) 제시되었다. 하지만 이러한 비유 창성 유형이 말더듬 초기부터 처음부터 질적으로 다르게 시작되는 것인지, 아니면 점진적으로 변화하는 것인지에 대해서는 많은 논의 가 진행 중이다. 
Johnson과 동료들(1959)에 따르면 말더듬아동 집단은 100 단어 당 평균 11.02 회의 비정상적 비유창성 빈도를 보였고(전체 비유창성 의 $63 \%$ ), 일반아동 집단은 1.96 회(전체 비유창성의 $26 \%$ )를 보였다. 즉 말더듬아동이 일반아동보다 더 높은 빈도와 비율로 비정상적 비유창성을 보였다.

Yairi와 Lewis (1984)는 말더듬기 시작한지 2개월 이내의 2-3세 말더듬아동(여자 5명, 남자 5명)과 일반아동의 비유창성을 좀 더 세분화하여 분석하였다. 말더듬아동 집단에서 가장 많이 보인 비 유창성 유형의 순서는 (1) 단어부분반복, (2) 비운율적발성 및 (3) 일 음절단어반복 순이었다. 말더듬아동집단과 일반아동집단을 비교 한 결과, 말더듬아동이 일반아동보다 3 배 더 많은 비유창성 빈도를 보였고, 훨씬 더 많은 단어부분반복과 비운율적발성을 보였다. 단 어부분반복시, 단위반복 횟수는 일반아동은 1 회(1-2회)를 보였지 만, 말더듬아동은 보통 2회 이상(1-11회)을 보였다.

Yairi (1997)는 진성비유창성(stuttering like disfluencies, SLD) 유형을 제안하며 초기 말더듬아동의 비유창성 특성을 분석하였 다. SLD 유형에는 단어부분반복, 일음절단어반복, 비운율적발성 그리고 긴장된 심을 들 수 있다. 초기 말더듬아동에게 나타난 비유 창성 특징으로 모든 비유창성 유형을 보였지만 일반아동보다 SLD 빈도는 5-6배 정도 많이 나타났고, 일반아동은 주로 2회 이하의 단 어부분반복 빈도를 보였다. SLD가 말더듬아동의 전체 비유창성의 $66 \%$ 를 차지하지만, 일반아동은 $28 \%$ 만 차지하였으며, 단어부분반 복은 말더듬아동에게 가장 빈도가 높은 유형이고, 다음으로 일음 절단어반복과 비운율적발성 순으로 나타났다. 반면에 일반아동에 게서는 단어반복도 자주 나타나지 않고 비운율적발성도 거의 나타 나지 않았다. Yairi (1997)는 이러한 연구결과를 근거하여 이 세 가 지 이외의 다른 비유창성 유형은 말더듬아동과 일반아동을 구별 하는 역할을 하지 못한다고 하였다. 국내 연구에서도(Chon, Ko, \& Shin, 2004) 4, 5세 말더듬아동에게서 단어부분반복이 가장 빈번 하였으며, 막힘과 연장 등을 포함하는 비전형적 비유창성이 전체 비유창성의 $54 \%$ 를 차지한다고 보고되었다.

이러한 선행연구들의 결과를 종합해 보면, 말더듬아동들이 보이 는 비유창성 유형은 양적, 질적인 측면에서 말더듬 초기부터 다르며, 말더듬아동이 보이는 SLD는 일반아동이 보이는 OD (other disfluencies, OD)와는 변별되는 유형이며 시간이 지남에 따라 말더듬의 변화를 가장 민감하게 살펴볼 수 있는 임상적 지표로서 사용될 수 있다(Yairi, Ambrose, \& Niermann, 1993).

한편 정상적 비유창성과 비정상적 비유창성의 빈도가 어떻게 시 간의 흐름에 따라 변화하는가를 파악한 종단연구가 Yairi의 연구 진에 의해 체계적으로 진행되었다. Yairi (1982)의 연구에 의하면 33
명의 일반아동을 대상으로 종단적으로 자발화를 수집하여 아동 들이 보이는 비유창성 유형의 변화를 분석한 결과, 2-3세 경에 비유 창성을 많이 보이기 시작하여 시간이 지남에 따라 수정과 구반복 이 증가하고, 단어부분반복과 간투사는 줄어드는 것으로 나타났 다. 따라서 정상적 비유창성과 말더듬을 구분할 수 있는 비정상적 비유창성 유형으로 단어부분반복이 포함될 수 있음을 보여주었다.

또한 Yairi와 Ambrose (1999)는 말더듬이 시작된지 12개월 이내 인 147명 취학 전 아동을 대상으로 말더듬이 지속되거나 혹은 자연 회복된 초기 아동기 말더듬 특징을 시간의 변화에 따라 어떻게 변 화하는가를 살펴보았다. 연구 결과, 말더듬을 회복한 아동들의 경 우 말더듬 초기에는 말더듬 빈도와 중증도가 최고조에 달하였다가, 1 년 이내에 다시 완화되는 경향을 보였다. Yairi와 Ambrose (1999) 는 말더듬 발생 후 말더듬 수준이 1년 동안 일정하게 유지된다면 말 더듬이 지속될 수 있는 징후로 볼수 있다고 하였다.

말을 더듬기 시작한지 12 개월 이내의 어린 말더듬아동을 대상으 로 한 Yairi와 Ambrose (2005)의 연구에 의하면 말더듬아동이 100 음절 당 말소리 및 음절반복 횟수가 일반아동보다 9 배 더 많이 보였 으며, 비운율적발성 횟수는 일반아동보다 3 배 더 많이 보였다.

위에서 언급한 종단연구들의 연구결과는 다음과 같이 요약된다. 연구마다 수치가 상이하지만 말더듬아동의 SLD 비율이 $65 \%$ 이상 이며, 일반아동은 $50 \%$ 이하라는 초기 아동기 말더듬 특성에 근거 하여 SLD가 말더듬아동과 일반아동을 변별할 수 있는 유형이라고 볼 수 있다(Yairi, 1997). 또한 아동이 보이는 빈번한 SLD는 부모로 하여금 아동이 말을 더듬기 시작했다고 판단하는 데 중요한 영향 을 줄수 있으며, SLD 비율이 말더듬 여부를 판단하는 데 중요한 요 인이라 볼수 있다(Yairi \& Ambrose, 2005).

따라서 본 연구는 2-5세 초기 말더듬아동을 대상으로 하여 말더 듬을 치료하면서 18 개월 동안 SLD 유형 및 빈도를 종단적으로 분 석하여 말더듬의 지속 및 회복과 관련된 변화양상을 살펴보고자 하였다.

\section{연구방법}

\section{연구대상}

본 연구는 만 2 세 6 개월-5세 4 개월의 발달성 말더듬아동 18 명을 대상으로 하였다. (1) 부모가 말더듬이라고 하였으며, 말더듬이 시 작된 지 12 개월 이내라고 보고하였으며, (2) 파라다이스-유창성검 사-II (P-FA-II; Sim, Shin, \& Lee, 2010) 검사 결과, '중간' 이상의 유 창성장애로 진단받았으며, (3) 아동의 자발화 분석결과, SLD 빈도 가 100 음절 당 3 회 이상이며, (4) 수용 및 표현어휘력검사(REVT; 
Kim, Hong, Kim, Jang, \& Lee, 2009)의 수용어휘력검사 점수가 -1 표준편차 이상이며, (5) 동일한 구성의 말더듬 치료를 받았으며, (6) 동반된 장애가 없는 아동을 연구 대상으로 선정하였다.

연구 대상자는 말더듬 진단 후, 18 개월 시점에 다음과 같은 기준 으로 분류되었다. '말더듬 지속집단’은 (1) 언어치료사 및 부모가 아 동이 말더듬을 계속 보인다고 보고하였으며, (2) SLD 빈도가 100음 절 당 3회 이상이며, (3) P-FA-II (Sim et al., 2010) 검사 결과, '중간' 이상으로 나타나며, ‘말더듬 회복집단'은 (1) 언어치료사 및 부모가 아동이 말더듬 문제를 보이지 않는다고 보고하였으며, (2) SLD 빈 도가 100음절 당 3회 미만이며, (3) P-FA-II (Sim et al., 2010) 검사 결과, 말더듬 정도가 백분위수가 가장 낮은 '약함’으로 진단받았다. 집단별 초기정보는 Table 1 과 같다.

집단 간 평가 시 다양한 변인들인 치료기간, 말더듬 시작연령, 생 활연령, 말더듬 정도, 100 음절 당 SLD 빈도, 말더듬 지속기간, REVT 점수에 대한 동질성 검정을 위해 일원분산분석(one-way ANOVA) 을 실시하였다. 집단간의 동질성 검정 결과, 치료기간, 말더듬 시작

Table 1. Participants' characteristics

\begin{tabular}{lcc}
\hline Characteristic & $\begin{array}{c}\text { Recovery group } \\
(\mathrm{N}=12)\end{array}$ & $\begin{array}{c}\text { Persistent group } \\
(\mathrm{N}=6)\end{array}$ \\
\hline Sex (male:female) & $8: 4$ & $4: 2$ \\
Age at initial visit (mo) & $44.9 \pm 9.9$ & $42.5 \pm 13.5$ \\
Age at onset (mo) & $38.7 \pm 11.3$ & $38.0 \pm 11.4$ \\
Estimated time post-onset (mo) & $5.8 \pm 3.7$ & $4.5 \pm 4.2$ \\
Stuttering severity & $3.6 \pm 0.7$ & $4.2 \pm 0.4$ \\
Frequency of SLD per 100 syllables & $7.5 \pm 4.4$ & $8.0 \pm 3.2$ \\
REVT test score & $50.5 \pm 12.0$ & $55.7 \pm 17.0$ \\
Therapy & & \\
$\quad$ Duration of therapy (mo) & $13.3 \pm 5.0$ & $18.0 \pm 0.0$ \\
Indirect only therapy & $2(17.0 \mathrm{mo})$ & $0(0 \mathrm{mo})$ \\
Both indirect and direct therapy & $10(83.0 \mathrm{mo})$ & $6(100 \mathrm{mo})$ \\
\hline
\end{tabular}

Values are presented as mean \pm SD.

$S L D=$ stuttering like disfluencies; REVT = Receptive \& Expressive Vocabulary Test (Kim, Hong, Kim, Jang, \& Lee, 2009).

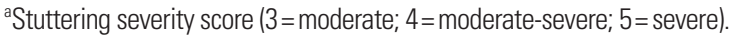

연령, 생활연령, 말더듬 지속기간, 말더듬 정도, 100 음절 당 SLD 빈 도, REVT 점수는 두 집단 간에 통계적으로 유의한 차이를 보이지 않았다( $p>.05)$. 집단 간에 치료기간은 통계적으로 유의한 차이를 보였다 $(F=5.275, p<.05)$.

\section{연구절차}

대상자로 선정된 아동들은 아래의 연구진행표에 따라 실험을 진 행하였다(Table 2).

모든 대상자에게 P-FA-II (Sim et al., 2010) 검사 및 REVT (Kim et al., 2009) 검사를 실시하여 대상자 선정기준에서 벗어나는 경우 대상자에서 제외하였다. 대상자로 선정된 아동들은 진단 후, 치료 (부모교육, 간접치료, 직접치료)를 받았고, 상호작용놀이 발화를 4 차례(3개월, 6 개월, 12 개월, 18 개월 시점) 수집 및 분석하였다.

\section{치료내용}

말더듬아동 치료는 크게 직접치료와 간접치료로 나뉘어지며, 부 모교육을 먼저 받고 간접치료와 직접치료를 받도록 구성하였다 (Lee \& Sim, 2016). 말더듬아동과 부모는 다음과 같은 치료에 참여 하였다. 첫째, 부모교육 프로그램에서 부모는 교육적인 상담을 받 았다. 말더듬아동 부모는 말더듬에 대해 정확히 알지 못하거나, 아 동 말더듬에 대해 여러 가지 잘못된 선입견을 가질 수 있으므로 말 더듬에 대해 정확하고 올바른 지식에 대한 상담을 받았다(Manning, 2010). 둘째, 간접치료에서 부모는 부모 자신의 말.언어를 변 화시켜 아동의 유창성 증진 방법을 습득하였다. 간접치료 후 12 주 시점에 P-FA-II (Sim et al., 2010) 평가결과 말더듬으로 진단될 경우 직접치료를 실시하였다. 그러나, P-FA-II (Sim et al., 2010) 평가결과 '약함'으로 진단되고 또한 부모가 더듬지 않는다고 보고 할 경우 치 료를 종결하였다. 2 명의 회복집단 아동의 경우 간접치료 후 종결을 하였다. 셋째, 직접치료에서 부모는 치료에 관찰자로 참여하거나, 병 행하는간접치료의 참여자로서 역할을 수행하였다.

Table 2. Research progress schedule

\begin{tabular}{|c|c|c|}
\hline Research time & Treatment information & Data collection \\
\hline Initial visit (evaluation) & - & $\begin{array}{l}\text { Fluency formal test \& language formal test } \\
\text { Parent-child interaction assessment (1st) }\end{array}$ \\
\hline After 1 month & Parent education & - \\
\hline After 1.5 months & Interaction therapy start (12-week program) & - \\
\hline After 3 months & - & Parent-child interaction assessment (2nd) \\
\hline After 6 months & - & Parent-child interaction assessment (3rd) \\
\hline After 12 months & - & Parent-child interaction assessment (4th) \\
\hline After 18 months & - & Parent-child interaction assessment (5th) \\
\hline
\end{tabular}




\section{실험과제}

부모-아동 상호작용 평가에 나타난 아동의 100 개 발화와 아동발 화에 포함된 부모발화를 5 회 수집하였다. 부모-아동 상호작용 평가 는 ‘동물원놀이', '찰휽만들기'와 같이 아동에게 친숙한 장난감을 사 용하였다. 아동의 발화수가 부족하거나, 아동이 장난감에 무관심할 경우, 아동이 좋아하는 장난감을 사용하여 자료를 수집하였다.

부모-아동 상호작용놀이를 시작하기 전에 부모에게 가정에서처 럼 자연스러운 놀이상황이 될 수 있도록 ‘집에서처럼 놀이해주세 요!'라고 요청하였다.

\section{자료분석}

아동의 SLD 빈도 및 유형 분석

아동의 50 개 발화에 나타난 SLD 유형 및 100 음절 당 빈도를 분 석하였다. SLD 빈도 및 유형은 일음절단어반복, 단어부분반복, 비 운율적발성의 빈도 및 유형을 분석하였다. 두 개의 SLD 유형이 동 시에 나타날 경우(예: 연장 동반한 음절반복)에는 2 개의 SLD 유형 으로 집계하였다(Ambrose \& Yairi, 1999).

\section{중재충실도}

치료효과에 대한 연구로 통일된 중재를 하기 위해 다음과 같은 절차를 적용하였다.

첫째, 본 연구자와 언어재활사 4 명은 모두 1 급 언어재활사 $(\mathrm{B}, \mathrm{C}$, $\mathrm{D}, \mathrm{E})$ 이며 동일한 임상 연구소에서 동일한 유창성장애 평가 및 치 료에 대한 전문가수련을 받아 치료구성 및 절차에 대한 동질성을 확보하였다.

둘째, 상호작용 평가를 수행한 평가, 3,6 개월 시점에 본 연구자는 언어재활사 B, C, D, E와 아동의 상태와 치료내용(전체구성, 회기 구성, 종결)에 대한 논의를 하고 치료에 반영하였다.

셋째, 언어재활사의 중재 성공률은 $\mathrm{D}$ 를 제외하고는 모두 $50 \%$ 이 상으로 언어재활사에 따른 중재차이는 나타나지 않았다. $\mathrm{D}$ 의 경우 는 대상자가 유일하게 1 명으로 지속집단에 포함되어 중재 성공률 이 낮았다.

\section{평가자 간 신뢰도}

전체 자료의 $20 \%$ 에 해당하는 4 명의 자료를 유창성장애 평가 및 치료경험이 있으며 언어치료사 자격증을 소지한 유창성장애 전문 가 2 명과 본 연구자가 독립적으로 전사하고 아동의 SLD 빈도, 유형 을 분석하여 신뢰도를 산출하였다. SLD 빈도의 신뢰도 산출 공식 은 다음과같다.
평가자 간 신뢰도 $(\%)=\frac{\text { 일치한 SLD 빈도의 수 }}{\text { 발화에서 나타난 SLD 빈도의 총수 }} \times 100$

아동의 SLD 빈도, 유형의 평가자 간 신뢰도는 $93.5 \%, 91 \%$ 였다.

\section{통계처리}

아동집단의 시점별 SLD 유형 및 빈도 변화를 살펴보기 위해 반 복측정 분산분석(repeated measured ANOVA)을 사용하여 분석 하였다. 또한, 구형성 가정을 만족시키는지 살펴보기 위하여 Mauchly의 구형성 검정을 실시하여 구형성 가정을 만족시켰고 만족하 지 못한 요인(일음절단어반복)인 경우에는 Greenhouse-Geisser값 으로 결과를 분석하였다.

\section{연구결과}

\section{시점별 SLD 빈도 및 유형의 변화}

집단(회복집단, 지속집단)별로 시점에 따른 100 음절 당 SLD 빈 도, 일음절단어반복, 단어부분반복, 비운율적발성의 기술통계는 Table 3에 제시하였다.

\section{시점별 SLD 빈도 변화 양상}

Figure 1은 두 집단의 SLD 빈도 변화를 시점별로 제시하였다.

두 집단의 SLD 유형 차이를 시점별로 살펴보기 위하여 반복측 정 분산분석을 실시한 결과는 Table 4 와같다.

SLD 빈도에 대한 집단의 주효과가 유의하게 나타났다 $\left(F_{(1,16)}=\right.$ $4.904, p<.05)$. 즉, 지속집단의 SLD 빈도가 회복집단에 비해서 유 의하게 높았다. 시점에 대한 주효과도 유의하게 나타났다 $\left(F_{(4,64)}=\right.$

Table 3. Descriptive statistics for SLD by group

\begin{tabular}{lccccc}
\hline & Initial visit & 3 months & 6 months & 12 months & 18 months \\
\hline Mean age (mo) & 43.5 & 46.5 & 49.5 & 55.5 & 61.5 \\
Recovered (N=12) & & & & & \\
SWR & $3.1(2.0)$ & $2.1(2.7)$ & $2.6(2.7)$ & $.6(.9)$ & $.2(.4)$ \\
PWR & $5.8(4.2)$ & $5.2(5.4)$ & $4.3(5.4)$ & $2.2(2.2)$ & $1.6(1.6)$ \\
DP & $12.8(13.0)$ & $10.1(10.3)$ & $6.4(12.3)$ & $1.4(1.5)$ & $.6(.6)$ \\
SLD frequency & $23.0(15.7)$ & $17.3(15.5)$ & $13.4(18.2)$ & $4.2(3.6)$ & $2.3(2.1)$ \\
Persistent (N=6) & & & & & \\
SWR & $4.2(1.7)$ & $3.7(1.6)$ & $2.0(1.1)$ & $2.2(1.0)$ & $2.8(2.5)$ \\
PWR & $4.7(3.4)$ & $8.0(8.0)$ & $4.2(1.5)$ & $7.0(4.3)$ & $7.0(4.3)$ \\
DP & $12.0(4.8)$ & $12.7(9.4)$ & $6.2(1.7)$ & $12.5(6.4)$ & $13.8(4.9)$ \\
SLD frequency & $20.3(7.7)$ & $23.5(17.7)$ & $11.0(1.8)$ & $21.8(10.1)$ & $26.2(13.1)$ \\
\hline
\end{tabular}

Values are presented as mean (SD).

$S L D=$ stuttering like disfluencies; SWR = single-syllable word repetition; $P W R=$ partword repetition; $\mathrm{DP}=$ disrhythmic phonation. 


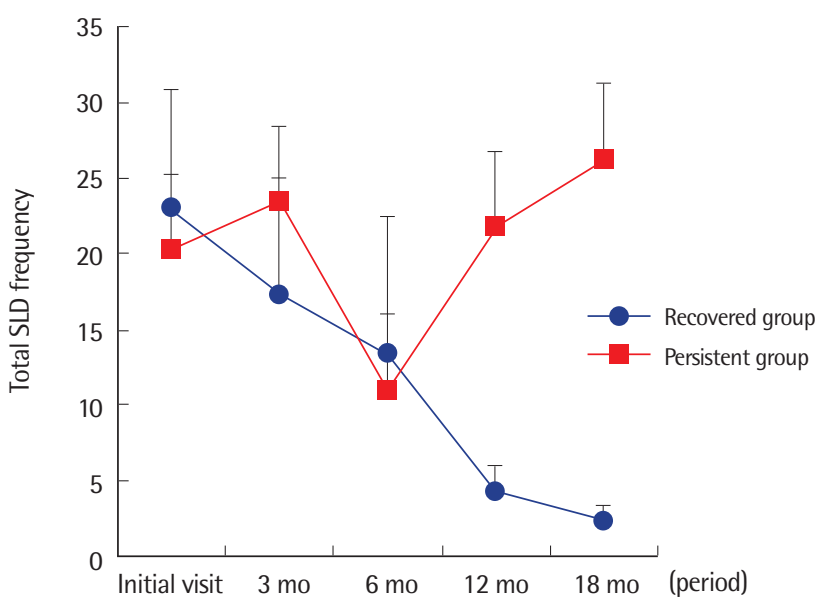

Figure 1. Changes in total stuttering like disfluencies (SLD) frequency in persistent and recovered groups.

Table 4. Repeated measures ANOVA results for the total SLD frequency by group

\begin{tabular}{lrrrrrc}
\hline Group & $\begin{array}{c}\text { Sum of } \\
\text { squares }\end{array}$ & $d f$ & $\begin{array}{c}\text { Mean } \\
\text { square }\end{array}$ & $F$ & $p$-value & partial $\eta^{2}$ \\
\hline Between subjects & & & & & & \\
$\quad$ Group (A) & $2,531.250$ & 1 & $1,531.250$ & $4.904^{*}$ & .042 & .235 \\
$\quad$ Error & $4,995.650$ & 16 & 311.228 & & & \\
Within subjects & & & & & & \\
$\quad$ Time (B) & $1,375.244$ & 4 & 401.341 & $3.006^{*}$ & .032 & .158 \\
A×B & $2,283.778$ & 4 & 660.480 & $4.992^{* *}$ & .003 & .238 \\
Error & $7,319.933$ & 64 & 133.512 & & & \\
\hline
\end{tabular}

${ }^{*} p<.05,{ }^{* *} p<.01$.

$3.006, p<.05)$. 대응별 비교 결과, 1 차평가- 6 개월 $(p<.05), 1$ 차평가 -12 개월 $(p<.05), 1$ 차평가- 18 개월 $(p<.05)$ 간의 SLD 빈도 차이가 유 의하게 컸다.

집단과 시점 조건이 SLD 빈도에 미치는 이차상호작용 효과가 통 계적으로 유의하였다 $\left(F_{(4,64)}=4.992, p<.01\right)$. 지속집단에서는 SLD 빈도가 6개월 시점에 감소하다가 12 개월 시점부터 다시 증가된 반 면에, 회복집단에서는 SLD 빈도가 평가시점부터 18 개월 시점까지 지속적으로 감소하였다. 시점별로 차이를 검정한 결과, 12 개월 시 점 $(p=.023), 18$ 개월 시점 $(p=.000)$ 에서 집단 간에 SLD 빈도 차이가 평가, 3,6 개월 시점에 비해서 유의하게 커져서 이차상호작용이 나 타난 것으로 판단된다.

\section{시점별 일음절단어반복 유형 변화}

Figure 2 는 두 집단의 일음절단어반복 유형의 변화를 시점별로 제시하였다.

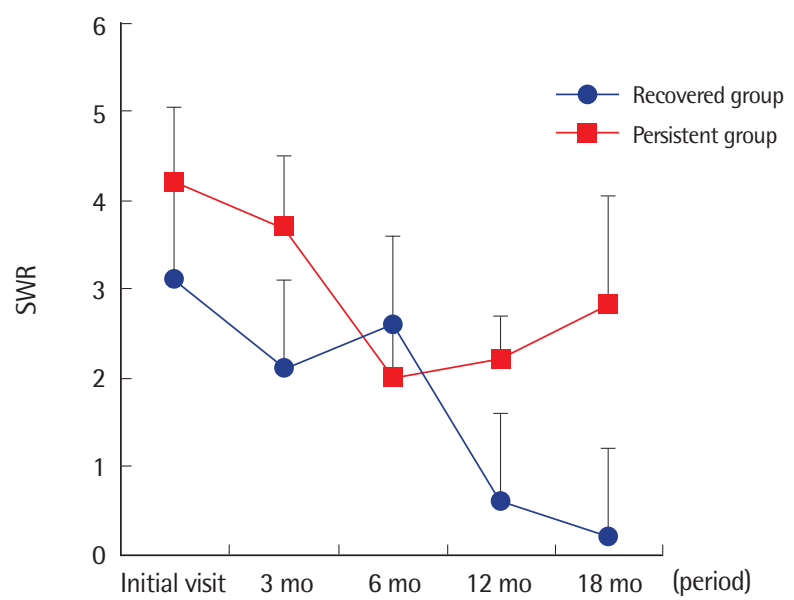

Figure 2. Changes in single syllable word repetition (SWR) of persistent and recovered groups.

Table 5. Repeated measures ANOVA results for single syllable word repetition by group

\begin{tabular}{lrrrcrc}
\hline Group & $\begin{array}{c}\text { Sum of } \\
\text { squares }\end{array}$ & $d f$ & $\begin{array}{r}\text { Mean } \\
\text { square }\end{array}$ & $F$ & $p$-value & partial $\eta^{2}$ \\
\hline Between subjects & & & & & & \\
$\quad$ Group (A) & 32.089 & 1 & 32.089 & $6.295^{*}$ & .023 & .282 \\
$\quad$ Error & 81.567 & 16 & 5.098 & & & \\
Within subjects & & & & & & \\
Time (B) & 57.222 & 4 & 14.306 & $4.541^{* *}$ & .003 & .221 \\
A $\times$ B & 22.467 & 4 & 5.617 & 1.783 & .143 & .100 \\
Error & 201.600 & 64 & 3.150 & & & \\
\hline
\end{tabular}

${ }^{*} p<.05,{ }^{* *} p<.01$.

두 집단의 일음절단어반복의 시점별 차이를 살펴보기 위하여 반 복측정 분산분석을 실시한 결과는 Table 5 와 같다.

일음절단어반복에 대한 집단의 주효과가 유의하게 나타났다 $\left(F_{(1,16)}=6.295, p<.05\right)$. 즉, 지속집단의 일음절단어반복 빈도가 회 복집단에 비해서 유의하게 높았다. 일음절단어반복에 대한 시점에 대한 주효과도 유의하게 나타났다 $\left(F_{(4,64)}=4.541, p<.01\right)$. 대응별 비 교 결과, 1 차평가- 12 개월 $(p<.05)$. 1 차평가- 18 개월 $(p<.05)$ 의 차이 가 유의하게 컸다. 집단과 시점 조건이 일음절단어반복에 미치는 이차상호작용 효과는 통계적으로 유의하지 않았다 $\left(F_{(4,64)}=1.783\right.$, $p>$.05).

\section{시점별 단어부분반복 유형 변화}

Figure 3 은 두 집단의 단어부분반복 유형의 변화를 시점별로 제 시하였다.

두 집단의 단어부분반복의 시점별 차이가 있는지를 살펴보기 위 


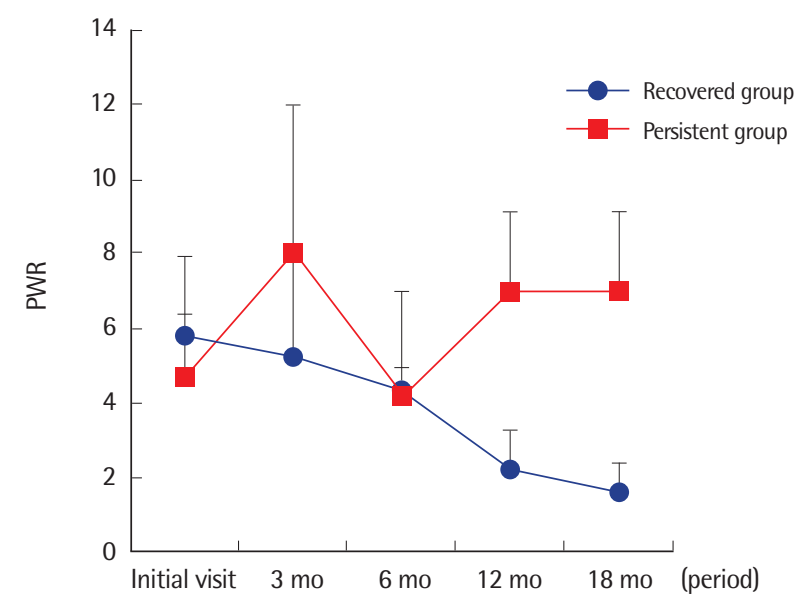

Figure 3. Changes in part-word repetition (PWR) in persistent and recovered groups.

Table 6. Repeated measures ANOVA results for part-word repetition by group

\begin{tabular}{lrrrrrr}
\hline Group & $\begin{array}{c}\text { Sum of } \\
\text { squares }\end{array}$ & $d f$ & $\begin{array}{c}\text { Mean } \\
\text { square }\end{array}$ & $F$ & $p$-value & partial $\eta^{2}$ \\
\hline Between subjects & & & & & & \\
$\quad$ Group (A) & 112.022 & 1 & 112.022 & 4.028 & .062 & .201 \\
$\quad$ Error & 444.967 & 16 & 27.810 & & & \\
Within subjects & & & & & & \\
$\quad$ Time (B) & 67.589 & 4 & 15.147 & .923 & .456 & .055 \\
A B B & 135.700 & 4 & 33.925 & 2.067 & .095 & .114 \\
$\quad$ Error & $1,050.367$ & 64 & 16.412 & & & \\
\hline
\end{tabular}

하여 반복측정분산분석을 실시한 결과는 Table 6과 같다.

단어부분반복에 대한 집단의 주효과가 유의하지 않았다 $\left(F_{(1,16)}=\right.$ $4.028, p>.05)$. 단어부분반복에 대한 시점에 대한 주효과도 유의하 지 않았다 $\left(F_{(4,64)}=.923, p>.05\right)$. 단어부분반복에 대한 집단과 시점 조건의 이차상호작용효과도 유의하지 않았다 $\left(F_{(4,64)}=2.067, p>.05\right)$.

\section{시점별 비운율적발성 유형 변화}

Figure 4 는 두 집단의 비운율적발성 유형의 변화를 시점별로 제 시하였다.

두 집단의 비운율적발성의 시점별 차이가 있는지를 살펴보기 위 하여 반복측정분산분석을 실시한 결과는 Table 7 과 같다.

비운율적발성에 대한 집단의 주효과가 유의하지 않았다 $\left(F_{(1,16)}=\right.$ $2.968, p>.05)$. 비운율적발성에 대한 시점의 주효과는 통계적으로 유의하였다 $\left(F_{(4,64)}=2.962, p<.05\right)$. 대응별 비교 결과, 1 차평가-6개 월 $(p<.01)$ 의 차이가 유의하게 컸다. 집단과 시점 조건이 비운율적 발성에 미치는 이차상호작용 효과는 유의하게 나타났다 $\left(F_{(4,64)}=\right.$ $4.000, p<.01)$. 시점별로 차이를 검정한 결과, 12 개월 시점 $(p=.001)$,

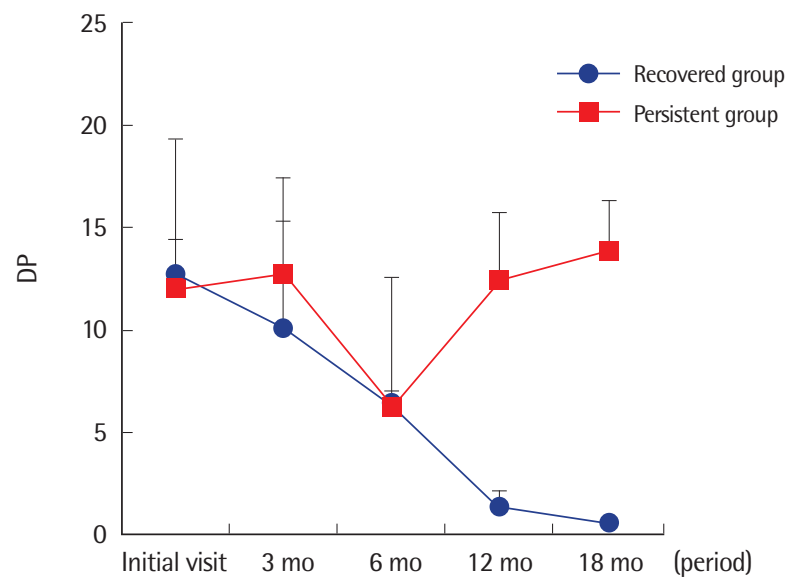

Figure 4. Changes in disrhythmic phonation (DP) of persistent and recovered groups.

Table 7. Repeated measures ANOVA results for disrhythmic phonation by group

\begin{tabular}{lrrrrrr}
\hline Group & $\begin{array}{r}\text { Sum of } \\
\text { squares }\end{array}$ & $d f$ & $\begin{array}{c}\text { Mean } \\
\text { square }\end{array}$ & $F$ & $p$-value & $\begin{array}{c}\text { partial } \\
\eta^{2}\end{array}$ \\
\hline Between subjects & & & & & & \\
$\quad$ Group (A) & 533.889 & 1 & 533.889 & 2.968 & .104 & .156 \\
$\quad$ Error & $2,877.900$ & 16 & 179.869 & & & \\
Within subjects & & & & & & \\
$\quad$ Time (B) & 510.644 & 4 & 127.661 & 2.962 & $.026^{*}$ & .156 \\
A×B & 689.444 & 4 & 172.361 & 4.000 & $.006^{* *}$ & .200 \\
Error & $2,757.933$ & 64 & 43.093 & & & \\
\hline
\end{tabular}

${ }^{*} p<.05,{ }^{* *} p<.01$.

18 개월 시점 $(p=.000)$ 에서 집단 간에 비운율적발성의 빈도 차이가 1 차평가, 3,6 개월 시점에 비해서 유의하게 커져서 이차상호작용효 과가 나타났다.

\section{시점별 SLD유형 비율 변화}

Figure 5는 두 집단의 SLD 유형의 시점별 비율의 변화를 그래프 로 나타낸 것이다. 회복집단은 비운율적발성의 경우 6개월 시점 이 후 지속적인 감소를 보였으나 지속집단은 큰 차이가 없는 것으로 나타났다. 일음절단어반복에서도 회복집단은 12 개월 시점부터 감 소추세를 보였으나지속집단은 비슷한 추이를 보였다.

\section{논의 및 결론}

본 연구는 2-5세 초기 말더듬아동을 대상으로 하여 말더듬을 치 료하면서 18 개월 동안 SLD 유형 및 빈도를 종단적으로 분석하여 

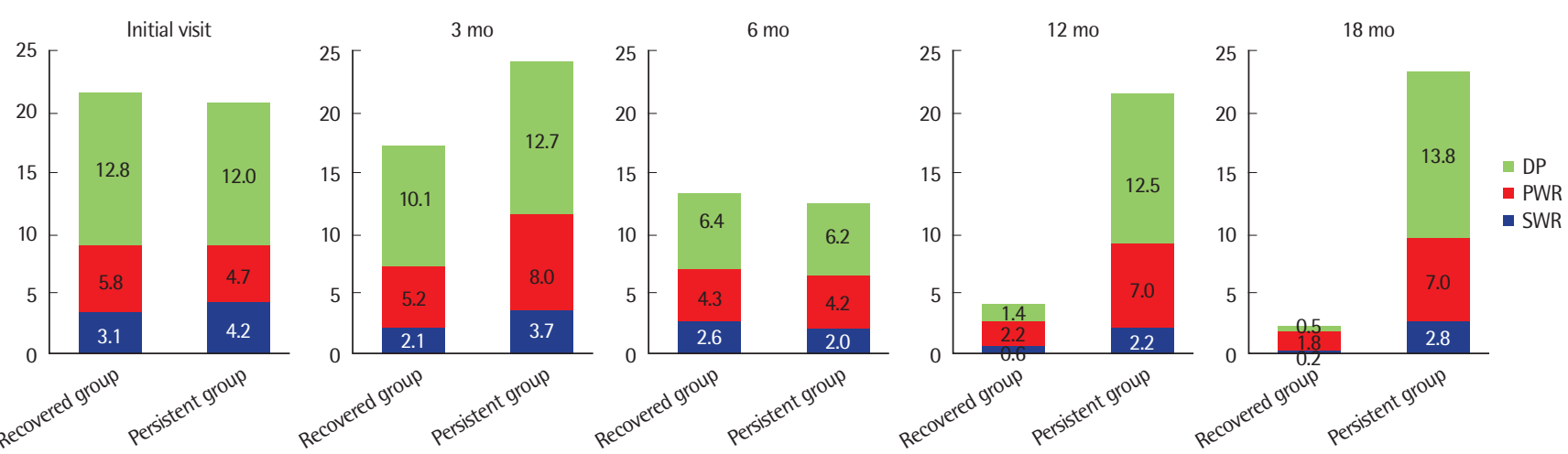

Figure 5. Changes in ratio of stuttering like disfluencies (SLD) types.

$\mathrm{DP}=$ disrhythmic phonation; PWR = part-word repetition; single syllable word repetition.

말더듬의 지속 및 회복과 관련된 변화양상을 살펴보는 데 목적이 있었다. 이를 위해 18 명의 말더듬아동을 진단 및 치료 후 18 개월 시 점에 말더듬 회복집단, 지속집단으로 나누고, 집단 간 SLD 빈도, 유 형 및 비율의 변화 양상 차이를 시점별로 비교 분석하였다.

지속집단과 회복집단의 SLD 빈도, 유형 및 비율의 변화를 요약 해보면 다음과 같다.

첫째, 지속집단과 회복집단의 SLD 빈도를 종단적으로 분석한 결과 회복집단에서는 감소하고 지속집단에서는 증가하는 추세를 보였다. SLD 빈도의 집단간 차이가 1 차 평가시점에 비해 12 개월 및 18 개월 시점에서 유의미하였다.

본 연구에서 SLD 빈도의 변화를 종단적으로 분석해 보면, 지속 집단과 회복집단 모두에서 6개월 시점 이후부터 변화가 관찰되기 시작했다. 말더듬 발생 후 6-18개월 이내에 SLD 빈도의 급격한 감소 가 나타난다는 선행연구(Yairi \& Ambrose, 1999; Yairi et al., 1993) 결과와 마찬가지로, 본 연구에서도 회복집단에서는 평가 후 6-12개 월 사이에 급격하게 감소하여, 이 시기가 회복집단과 지속집단의 특성이 변별될 수 있는 중요한 시점으로 보인다.

본 연구의 회복집단아동들의 초기평가를 실시할 당시 말을 더듬 기 시작한지 평균 5.8 개월이고 치료를 받은 지 6개월 이후부터 SLD 변화를 보이기 시작하였다. 즉, 말더듬 발생 후 12 개월 전후에 말더 듬 감소가 관찰되었다. 이러한 연구결과는 말더듬 발생 후 첫 12 개 월 전후의 비유창성의 감소추세를 말더듬 회복에 대한 강력한 긍정 적 지표로 제시한 Yairi와 Ambrose (2005)의 연구결과와 일치한다. 그러나 지속집단은 치료 시작 후 18 개월 동안 상승추세를 보였는데 이러한 패턴은 지속집단의 특징으로 볼 수 있으며 말더듬이 지속될 가능성이 높음을 나타낸다(Yairi \& Ambrose, 2005). 두 집단의 SLD 빈도의 변화 정도는 평가시점과 비교하여 18 개월 시점에서 회복집 단은 $88 \%$ 의 감소를 보였고, 지속집단은 $23 \%$ 의 증가를 보였다.

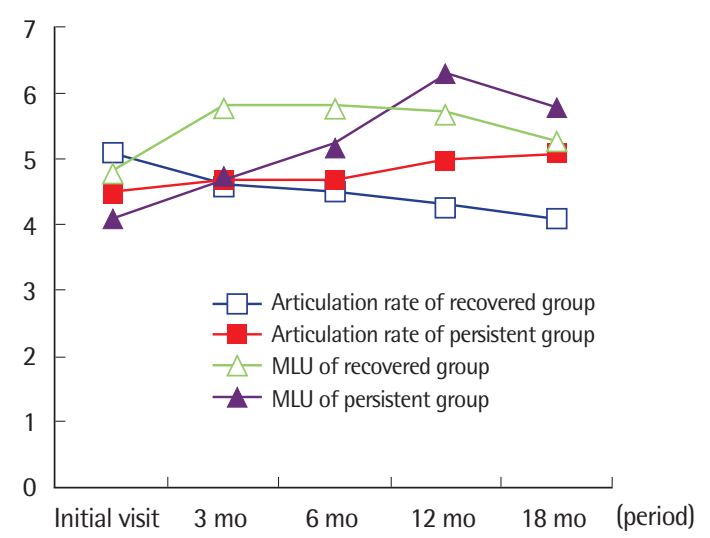

Figure 6. Changes in articulation rate and mean length of utterance (MLU) for persistent and recovered groups.

본 연구대상의 아동에게 동일한 치료가 제공되었으나 말더듬 회 복집단과 비교했을 때 말더듬 지속집단에서 SLD 빈도가 증가한 이유를 Figure 6에 제시한 집단별 문장길이 및 조음속도가 시점에 따라 어떠한 변화가 있는가를 고려해 보면 유추할 수 있다. (1) 간접 치료와 직접치료를 통해 발화길이를 짧게 하도록 지도하여도 두 집 단의 유창한 발화길이는 6개월 시점까지 동일하게 증가하는 경향 을 보였다(Lee \& Sim, 2015). 두 집단 모두 유창한 발화길이가 길어 진 점에서는 치료효과가 동일하지만, 전체 및 비유창한 발화길이에 서는 두 집단이 다른 양상을 보였다. 1 차평가시점에는 회복집단은 지속집단보다 전체 발화길이가 길었지만 직접치료 후인 6 개월 시점 부터는 발화길이가 증가하지 않고 감소하는 경향을 보였다. 하지만 지속집단은 발화길이가 계속 증가하는 추세를 보여 12 개월 시점부 터는 회복집단보다 더 긴 발화길이를 보였다. 지속집단은 발화길이 의 증가와 더불어 6 개월 시점부터 SLD 빈도가 증가하는 양상을 보 였다. (2) 회복집단은 평가 후 간접치료가 적용된 3개월 시점부터 
조음속도가 감소하는 경향을 보였지만 지속집단은 조음속도가 오 히려 더 빨라지는 경향을 보여 치료에 대한 반응도가 두 집단 간에 다른 것으로 나타났다. 특히, 회복집단의 경우 SLD 빈도가 급격히 감소하는 12 개월 시점에는 조음속도가 더 느려졌으나 지속집단의 경우 SLD 빈도가 급격히 증가하는 12 개월 시점에는 조음속도가 더 빨라지는 경향을 보였다. 18 개월 동안 조음속도가 빨라진 지속 집단은 SLD 빈도가 지속적으로 증가하였지만, 반대로 조음속도가 느려진 회복집단은 SLD 빈도가 감소하는 경향을 보였다.

둘째, 지속집단과 회복집단의 일음절단어반복, 단어부분반복, 비운율적발성에 나타난 특성은 회복집단에서는 18 개월간 감소하 고 지속집단에서는 증가하는 추세를 보여 두 집단을 변별하는 요 인이었다. Yairi와 Ambrose (2005)는 SLD 유형의 빈도보다 더 집단 을 미세하게 구분 지을 수 있는 3 가지 요소로 일음절단어반복, 단 어부분반복, 비운율적발성을 제시하였다. 본 연구에서는 일음절단 어반복은 집단과 시점의 주효과는 유의하였으나 이차상호작용효 과는 유의하지 않았고, 비운율적발성에서는 집단과 시점에 따른 이 차상호작용효과가 유의하게 나타나서 SLD 빈도 및 비운율적발성 유형이 집단간차이를 민감하게 보여주었다.

셋째, SLD 유형의 비율변화는 비운율적발성의 경우 6 개월 시점 이후 두 집단간에 큰 차이를 보였다.

따라서 본 연구의 임상적 의의는 초기 말더듬아동의 평가나 치 료 시 회복을 예측하기 위해서는 말더듬 시작 후 2년 동안의 SLD 빈도와 비운율적발성의 감소 추세를 확인하는 것이 중요하다는 점 을 제시하였으며, SLD 빈도와 비운율적발성의 변화를 통해 말더듬 치료의 시작과 종결을 점검하는 데 중요한 지표가 될 수 있음을 시 사하였다.

본 연구의 향후 연구를 위한 제언 및 제한점은 다음과 같다.

첫째, 말더듬아동의 다양한 요인들에 대한 장기적 관점에서 치 료효과를 예측한 연구가 거의 없기 때문에 말더듬 회복집단과 지 속집단에 대한 치료효과 비교연구는 찾아보기가 더 어려웠다. 선행 연구인 Yairi와 Ambrose (2005) 연구 역시 치료를 받지 않은 말더 듬아동의 종단연구이므로 치료 중에 나타난 변화양상을 살펴본 본 연구의 결과와 직접 비교하기에는 한계가 있었음을 밝혀둔다.

둘째, 향후 치료받지 않은 집단과 일반집단 대상자를 본 연구대상 자의 결과와비교를 하면 더 다양한 근거를 제시할 수 있을 것이다.

셋째, 회복집단과 지속집단의 피험자 수가 상이하기 때문에 통계 적 분석결과에 영향을 주었을 수 있다. 연구결과에 영향을 주지 않 을 정도의 두 집단의 동일한 인원수 및 다수의 인원확보가 필요하다.

넷째, 치료효과를 아동의 수집된 발화에 나타난 SLD 빈도의 양 적 데이터로만 파악하였으나 부모 보고나 아동의 의사소통태도 평
가 등의 질적인 데이터가 보완이 되면 또 다른 차원의 결과를 제시 할 수 있을 것이다.

\section{REFERENCES}

Ambrose, N., \& Yairi, E. (1999). Normative disfluency data for early childhood stuttering. Journal of Speech, Language, and Hearing Research, 42, 895-909.

Campbell, J., \& Hill, D. (1987). Systematic disfluency analysis: accountability for differential evaluation and treatment. Paper presented at the Annual Convention of American Speech, Language, and Hearing Association, New Orleans, LA.

Chon, H. C., Ko, D. H., \& Shin, M. J. (2004). Disfluency characteristics and speech rate of stuttering and nonstuttering. Korean Journal of Communication \& Disorders, 9, 102-115.

Johnson, W., \& Associates. (1959). The onset of stuttering: research findings and implications. Minneapolis, MN: University of Minnesota.

Kim, Y. T., Hong, K. H., Kim, K. H., Jang, H. S., \& Lee, J. Y. (2009). Receptive \& expressive vocabulary test (REVT). Seoul: Seoul Community Rehabilitation Center.

Lee, S. B., \& Sim, H. S. (2015). A longitudinal study of utterance length in morphemes as a predictor of treatment outcome in early childhood stuttering. Communication Sciences \& Disorders, 20, 189-201.

Lee, S. B., \& Sim, H. S. (2016). Predictor variables of the children's fluency in early stuttering intervention. Communication Sciences \& Disorders, 21, 382396.

Manning, W. H. (2010). Clinical decision making in fluency disorders (3rd ed.). Clifton Park, NY: Delmar/Cengage Learning.

Sim, H. S., Shin, M. J., \& Lee, E. J. (2010). Paradise-Fluency Assessment II. Seoul: Paradise Welfare Foundation.

Van Riper, C. (1982). The nature of stuttering (2nd ed.). Englewood Cliffs, NJ: Prentice-Hall.

Yairi, E. (1982). Longitudinal studies of disfluencies in two-year-old children. Journal of Speech, Language, and Hearing Research, 25, 155-160.

Yairi, E. (1997). Disfluencies characteristics of early childhood stuttering. In R. F. Curlee \& G. M. Siegel (Eds.), Nature and treatment of stuttering: new directions (2nd ed., pp. 49-78). Boston, MA: Allyn \& Bacon.

Yairi, E., \& Ambrose, N. G. (1992). A longitudinal study of stuttering in children: a preliminary report. Journal of Speech and Hearing Research, 35, 775760.

Yairi, E., \& Ambrose, N. G. (1999). Early childhood stuttering I: Persistence 
Soo-Bok Lee, et al. • Stuttering Like Disfluencies for Childhood Stuttering

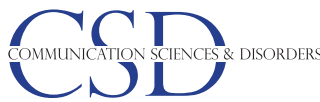

and recovery. Journal of Speech, Language, and Hearing Research, 42, 10971112

Yairi, E., \& Ambrose, N. G. (2005). Early childhood stuttering: for clinicians by clinicians. Austin, TX: Pro-Ed.

Yairi, E., \& Lewis, B. (1984). Disfluencies at the onset of stuttering. Journal of Speech and Hearing Research, 27, 155-159.

Yairi, E., Ambrose, N. G., \& Niermann, R. (1993). The early months of stut- tering: a developmental study. Journal of Speech and Hearing Research, 36, 521-529.

Yaruss, J. S. (1999). Utterance length, syntactic complexity, and childhood stuttering. Journal of Speech, Language, and Hearing Research, 42, 329-344.

Zebrowski, P. M. (2002). Stuttering. In J. B. Tomblin et al. (Eds.), Diagnosis in speech-language pathology (2nd ed., pp. 199-232). Clifton Park, NY: Delmar/Cengage Learning. 


\section{국문초록}

\section{취학 전 말더듬아동의 말더듬 치료시점별 진성비유창성 유형의 종단적 분석}

이수복 · 심현섭2

'우송대학교 언어치료·청각재활학과, ${ }^{20}$ 이화여자대학교 대학원 언어병리학과

배경 및 목적: 본 연구는 말더듬아동의 3 가지 진성비유창성(stuttering like disfluencies, SLD) 유형분석을 통해 18 개월 동안 치료시점 별 SLD 유형변화를 조사하였다. 후향적(retrospective) 연구로 말더듬 발생 1년 이내의 2-5세 말더듬아동을 대상으로 3가지 SLD 빈도 와 유형변화를 종단적으로 살펴보았다. 방법: 말더듬아동 18 명을 치료종료 시점인 18 개월 시점의 말더듬 정도와 SLD 빈도에 따라 12 명 회복집단과 6 명 지속집단으로 구분하였다. 부모-아동 상호작용놀이 상황에서 5 차례 발화를 수집하여 3 가지 SLD 유형(일음절단어반 복, 단어부분반복, 비운율적발성)과 비율변화, 빈도를 분석하였다. 결과: SLD 변화를 분석한 결과, 첫째, 회복집단은 치료가 진행됨에 따라 SLD의 총 빈도가 감소하였으나 지속집단은 SLD 빈도가 지속적으로 증가하였고, 둘째, 일음절단어반복은 집단과 시점의 주효과 는 유의하였으나 이차상호작용효과는 유의하지 않았고, 비운율적발성에서는 집단과 시점에 따른 이차상호작용효과가 유의하게 나타 났다. 셋째, SLD 유형의 비율변화는 비운율적발성의 경우 6개월 시점 이후, 일음절단어반복은 12 개월 시점부터 두 집단 간에 큰 차이를 보였다. 논의 및 결론: 말더듬 시작 후 18 개월간 SLD 빈도와 비운율적발성의 감소추세가 초기 말더듬아동의 회복을 예측하기 위한 근 거로 볼 수 있음을 시사한다. 임상 측면에서는 치료 과정에 나타난 SLD 빈도 및 비운율적발성 유형의 종단적 변화를 추적함으로써 초 기 말더듬아동의 비유창성 유형을 통한 치료결과를 예측할 수 있으며, 언어치료사는 말더듬 치료 후 12 개월 및 18 개월 시점의 SLD 빈 도 및 비운율적발성 유형의 변화에 주의를 기울일 필요성을 제안한다.

핵심어: 초기 말더듬아동, 진성비유창성, 종단연구, 회복집단, 지속집단

본 논문은 제1저자의 2014년 박사학위 논문을 수정·보완한 논문임.

\section{참고문헌}

김영태, 홍경훈, 김경희, 장혜성, 이주연(2009). 수용·표현어휘력검사(REVT). 서울: 서울장애인종합복지관.

심현섭, 신문자, 이은주(2010). 파라다이스 유창성 검사 II. 서울: 파라다이스 복지재단.

이수복, 심현섭(2015). 초기 말더듬아동의 치료후 말더듬회복 예측요인에 관한 종단연구: 발화길이를 중심으로. 언어청각장애연구, 20, 189-201.

이수복, 심현섭(2016). 초기 말더듬아동의 치료효과 예측변인 연구. 언어청각장애연구, 21, 382-396.

전희정, 고도흥, 신문자(2004). 유창성장애 아동과 정상 아동의 비유창성과 말 속도에 관한 비교 연구. 언어청각장애연구, 9, 102-115. 